\title{
Mercury in human brain, blood, muscle and toenails in relation to exposure: an autopsy study
}

\author{
Lars Björkman*1,2, Birgitte F Lundekvam ${ }^{1}$, Torgils Lægreid ${ }^{2}$, \\ Bjørn I Bertelsen 3 , Inge Morild ${ }^{3,4}$, Peer Lilleng3,4, Birger Lind ${ }^{5}$, Brita Palm ${ }^{5}$ \\ and Marie Vahter ${ }^{5}$
}

\begin{abstract}
Address: ${ }^{1}$ Dental Biomaterials Adverse Reaction Unit, Department of Health/UNIFOB, Årstadveien 17, NO-5009 Bergen, Norway, ${ }^{2}$ Department of Oral Sciences, University of Bergen, Årstadveien 17, NO-5009 Bergen, Norway, ${ }^{3}$ Department of Pathology, Haukeland University Hospital, NO5021 Bergen, Norway, ${ }^{4}$ Section for Pathology, The Gade Institute, University of Bergen, NO-5021 Bergen, Norway and ${ }^{5}$ Institute of Environmental Medicine, Karolinska Institutet, PO Box 210, SE-171 77 Stockholm, Sweden

Email: Lars Björkman* - Lars.Bjorkman@odont.uib.no; Birgitte F Lundekvam - Birgitte.Lundekvam@odont.uib.no; Torgils Lægreid - Torgils.Lagreid@odont.uib.no; Bjørn I Bertelsen - Bjorn.Inge.Bertelsen@helse-bergen.no; Inge Morild - Inge.Morild@gades.uib.no; Peer Lilleng - Peer.Lilleng@gades.uib.no; Birger Lind - Birger.Lind@imm.ki.se; Brita Palm - Brita.Palm@imm.ki.se; Marie Vahter - Marie.Vahter@imm.ki.se

* Corresponding author
\end{abstract}

Published: II October 2007

Environmental Health 2007, 6:30 doi:10.1186/1476-069X-6-30

This article is available from: http://www.ehjournal.net/content/6/I/30

(C) 2007 Björkman et al; licensee BioMed Central Ltd.

This is an Open Access article distributed under the terms of the Creative Commons Attribution License (http://creativecommons.org/licenses/by/2.0), which permits unrestricted use, distribution, and reproduction in any medium, provided the original work is properly cited.
Received: 29 June 2007

Accepted: II October 2007

\begin{abstract}
Background: The main forms of mercury $(\mathrm{Hg})$ exposure in the general population are methylmercury $(\mathrm{MeHg})$ from seafood, inorganic mercury $(\mathrm{I}-\mathrm{Hg})$ from food, and mercury vapor $\left(\mathrm{Hg}^{0}\right)$ from dental amalgam restorations. While the distribution of $\mathrm{MeHg}$ in the body is described by a one compartment model, the distribution of $\mathrm{I}-\mathrm{Hg}$ after exposure to elemental mercury is more complex, and there is no biomarker for $\mathrm{I}-\mathrm{Hg}$ in the brain. The aim of this study was to elucidate the relationships between on the one hand $\mathrm{MeHg}$ and $\mathrm{I}-\mathrm{Hg}$ in human brain and other tissues, including blood, and on the other $\mathrm{Hg}$ exposure via dental amalgam in a fish-eating population. In addition, the use of blood and toenails as biological indicator media for inorganic and organic mercury $(\mathrm{MeHg})$ in the tissues was evaluated.
\end{abstract}

Methods: Samples of blood, brain (occipital lobe cortex), pituitary, thyroid, abdominal muscle and toenails were collected at autopsy of 30 deceased individuals, age from 47 to 91 years of age. Concentrations of total- $\mathrm{Hg}$ and $\mathrm{I}-\mathrm{Hg}$ in blood and brain cortex were determined by cold vapor atomic fluorescence spectrometry and total- $\mathrm{Hg}$ in other tissues by sector field inductively coupled plasma-mass spectrometry (ICP-SFMS).

Results: The median concentrations of $\mathrm{MeHg}$ (total- $\mathrm{Hg}$ minus $\mathrm{I}-\mathrm{Hg}$ ) and $\mathrm{I}-\mathrm{Hg}$ in blood were 2.2 and $\mathrm{I} .0$ $\mu \mathrm{g} / \mathrm{L}$, and in occipital lobe cortex 4 and $5 \mu \mathrm{g} / \mathrm{kg}$, respectively. There was a significant correlation between $\mathrm{MeHg}$ in blood and occipital cortex. Also, total- $\mathrm{Hg}$ in toenails correlated with $\mathrm{MeHg}$ in both blood and occipital lobe. $\mathrm{I}-\mathrm{Hg}$ in both blood and occipital cortex, as well as total- $\mathrm{Hg}$ in pituitary and thyroid were strongly associated with the number of dental amalgam surfaces at the time of death.

Conclusion: In a fish-eating population, intake of $\mathrm{MeHg}$ via the diet has a marked impact on the $\mathrm{MeHg}$ concentration in the brain, while exposure to dental amalgam restorations increases the $\mathrm{I}-\mathrm{Hg}$ concentrations in the brain. Discrimination between mercury species is necessary to evaluate the impact on $\mathrm{Hg}$ in the brain of various sources of exposure, in particular, dental amalgam exposure. 


\section{Background}

Most people are to some degree exposed to mercury vapor via dental amalgam restorations, inorganic $\mathrm{Hg}^{2+}$ via food, methylmercury $\left(\mathrm{CH}_{3} \mathrm{Hg}^{+}\right)$via fish and sea mammals and thimerosal in vaccines [1]. In addition, some people are exposed to mercury in occupational settings. Dental personnel constitute one of the largest groups with occupational exposure to elemental mercury. Exposure may also occur in the production of electrical devices (batteries, switches, and fluorescent light bulbs) and in the production of chlorine and sodium hydroxide using electrolysis [1]. From a toxicological point of view the MeHg exposure via seafood and mercury vapor is the most important.

For decades the potential health risks from mercury exposure from dental amalgam restorations have been reviewed and evaluated [2-6]. It is well known that amalgam restorations continuously release elemental mercury vapor $[7,8]$, which is inhaled and absorbed by the body and distributed to tissues including the brain [9-11]. While it is clear that MeHg easily passes the blood brain barrier leading to higher levels of $\mathrm{MeHg}$ in brain than in blood, it is generally not believed that mercury in blood reflects the concentrations of inorganic mercury in the brain [12]. From a diagnostic point of view it is important to find out to what extent mercury levels in blood and other tissues may reflect concentrations of inorganic mercury in brain in a population with exposure to both methylmercury from fish and elemental mercury vapor from dental amalgam.

The aim of the present study was to explore the relationships between inorganic and organic mercury in brain (occipital lobe cortex) and in blood and other tissues in individuals without occupational exposure to inorganic mercury and to evaluate the use of blood and toenails as biological indicator media for inorganic and organic mercury $(\mathrm{MeHg})$ in brain and other tissues.

\section{Methods}

\section{Study population and sampling}

In conjunction with routine autopsies at the Department of Pathology and the Department for Forensic medicine, the Gade Institute, Haukeland University Hospital, Bergen, Norway, samples from occipital lobe, thyroid gland, pituitary gland, abdominal muscle, toenails and blood from vena femoralis and the heart were collected from 30 deceased individuals. All autopsies were carried out within 3 days after death. Occupational exposure to mercury was used as an exclusion criterion. An equal distribution of men and women was aimed at.

Oral examination was carried out in every case. All dental restorations were recorded. Tooth surfaces filled with amalgam, composites or gold, and number of metallocer- amic crowns, partial or complete fixed and removable dentures, and missing teeth were noted. Information on current and previous use of tobacco was obtained from the present hospital record as well as information on alcohol abuse, diseases and medication.

The project protocol was approved by the Regional Committee for Medical Research Ethics in Western Norway (\#173.02), reviewed in relation to privacy and license requirements according to the Personal Data Registers Act by the Norwegian Social Science Data Services. According to Norwegian legislation the study was approved and registered as a temporary biobank by the Ministry of Health. Permission for sending human tissue samples for analyses out of Norway was given by the Directorate for Health and Social Affairs.

\section{Sampling procedure}

Duplicate samples of blood from vena femoralis were collected after removal of the intestines by squeezing the blood out of the vene into a beaker. The samples were transferred into glass tubes with heparin as anticoagulant (BD Vacutainer ${ }^{\circledR}$ Trace Element Tube, sodium heparin 119 IU, Becton Dickinson, UK), mixed well and transferred into polypropylene tubes (Sarstedt AG Co., Germany). Samples of blood from the heart were collected by aspiration into a syringe using a stainless steel cannula before the heart was opened. The samples were then treated as blood from vena femoralis. In some cases it was not possible to aspirate blood from the heart. Duplicate samples (about 3-4 g each) were collected from the occipital lobe by use of an acid washed scalpel $\left(10 \% \mathrm{HNO}_{3}\right)$ to minimize contamination and transferred into polypropylene tubes (Sarstedt AG Co., Germany). Samples from abdominal muscle $(\mathrm{n}=30)$, pituitary $(\mathrm{n}=30)$, thyroid $(\mathrm{n}=28)$ and toenails $(\mathrm{n}=29)$ were also collected. Generally, nails were clipped prior to the autopsy, and only small samples with a length of about $1 \mathrm{~mm}$ were available for collection. Clippings were collected from all toenails using a stainless steel scissors. Samples between 7.6 to $68 \mathrm{mg}$ were used for analysis. All samples were frozen the same day and stored at $-80^{\circ} \mathrm{C}$. Before analysis, samples from occipital lobe were placed on a hydrocarbon wax film (Parafilm $\mathrm{M}^{\circledast}$, SPI Supplies Division, Structure Probe Inc., West Chester, PA, USA) and the gray matter (cortex) was separated from the white matter of the samples using acid washed instruments. Only the gray matter was analyzed for mercury.

\section{Analyses of inorganic and total mercury by CVAFS}

Samples of blood (from vena femoralis and the heart) and occipital lobe cortex were sent to Karolinska Institutet for speciation analyses of mercury. Briefly, the samples were solubilized in a mixture of L-cysteine $(1 \%), \mathrm{NaOH}(45$ $\%)$, and $\mathrm{NaCl}(1 \%)$. Tissue samples were heated to complete the solubilization. Subsequently the solubilized 
samples were subjected to reduction by $\mathrm{SnCl}_{2}$ (for the determination of inorganic mercury) or a mixture of $\mathrm{CdCl}_{2}$ and $\mathrm{SnCl}_{2}$ (for the determination of total mercury). Mercury was determined by an automated multiple injection cold vapor atomic fluorescence spectrometric system (CVAFS; Merlin, PSA 10.023; P.S. Analytical Ltd., Orpington, Kent, UK) as previously described for blood [13]. The instrumentation is described in detail elsewhere [14]. Concentration of MeHg in tissue was estimated by subtracting the I-Hg concentration from the total-Hg concentration. Mercury content was related to the wet weight of the sample.

\section{Analyses of mercury by ICP-SFMS}

Samples of blood from vena femoralis and of occipital lobe cortex, abdominal muscle, thyroid, pituitary gland, and toenails were analyzed for total mercury by double-focusing, sector field inductively coupled plasma-mass spectrometry (ICP-SFMS). The samples were subjected to microwave-assisted digestion with nitric acid as described previously for blood $[15,16]$, and other soft tissues [17] and nails $[18,19]$ at a commercial laboratory (ALS Analytica $\mathrm{AB}$, Luleå, Sweden) [20]. The toenails were not cleansed before analysis.

\section{Analytical quality control}

Reference materials LUTS-1 (non defatted lobster hepatopancreas; National Research Council of Canada/Institute for National Measurement Standards), Seronorm 404107X and Seronorm 404108 (whole blood; SERO A/ $\mathrm{S}$, Asker, Norway) were analyzed together with the samples as described for the analyses of inorganic and total mercury. For the analytical quality control of the analyses by ICP-SFMS the reference materials LUTS-1, SRM 8414 (bovine muscle powder; NIST), SRM 1577a (bovine liver; NIST) were used. Duplicate samples of blood from vena femoralis were analyzed for total mercury both at Karolinska Institutet using CVAFS and at Analytica AB using ICPSFMS giving an opportunity to compare the methods. Although it could be expected that the mercury concentrations in the duplicate samples from occipital lobe cortex were not identical, duplicate samples were analyzed for total mercury by both methods (CVAFS and ICP-SFMS). $\mathrm{MeHg}$ in the reference material LUTS-1 was in addition determined at Analytica $\mathrm{AB}$ after digestion in methanolic $\mathrm{KOH}$, extraction and ethylation of $\mathrm{MeHg}$ followed by determination by coupled gas chromatography-inductively coupled plasma mass spectrometry (GC-ICPMS) [21].

\section{Statistical methods}

Associations between concentrations of mercury in blood and tissues were evaluated statistically by correlational analyses. Multiple linear regression was used to evaluate the importance of background variables (age, gender) and exposure indicators (number of amalgam surfaces, $\mathrm{MeHg}$ in blood) on concentration of mercury concentration in tissue. A stepwise backward method was used, entering all independent variables (age, gender, number of amalgam surfaces, MeHg in blood) at the first step. In the following step $(s)$ the variables were removed, one at the time, if the assigned p-value was found to be 0.10 or higher. SPSS 13.0 (SPSS Inc., Chicago, IL, USA.) was used for the calculations.

\section{Results}

Tissue samples from 13 women and 17 men (overall mean age 68 years, range 47 to 91 years, standard deviation 11.8 years) were collected (Table 1 ). Scrutiny of the present hospital records did not in any case reveal current or previous occupational exposure to mercury. There were two cases with documented alcohol abuse and 10 had received blood transfusions during the last months. The individuals had on average 13.2 dental amalgam surfaces (range 0 to 50 surfaces).

The median concentrations of $\mathrm{MeHg}$ and $\mathrm{I}-\mathrm{Hg}$ in blood were 2.2 and $1.0 \mu \mathrm{g} / \mathrm{L}$, respectively (Table 2 ). At an average, the $\mathrm{MeHg} /$ total-Hg ratio in blood was 0.62 (SD 0.22, median 0.67 ) with a range from 0.18 to 0.95 . Mercury in tissue samples was related to the wet weight of the sample. In occipital lobe cortex the median concentrations of $\mathrm{MeHg}$ and I-Hg were 4 and $5 \mu \mathrm{g} / \mathrm{kg}$ wet weight, respectively. In one of the samples from occipital cortex the concentration of $\mathrm{I}-\mathrm{Hg}(164 \mu \mathrm{g} / \mathrm{kg})$ was 9 times higher than the concentration of the second highest case and fulfilled the criteria of an "extreme outlier" from a statistical point of view [22] (more than the value of the 75th percentile plus three times the inter quartile range). In order to get additional information on this case (woman, age 91), historical hospital records were examined and it was found that she had been employed as a dental assistant earlier in life. Therefore, the associations between number of amalgam surfaces and concentration of total- $\mathrm{Hg}, \mathrm{MeHg}$ and I-Hg in blood and tissues were analyzed both with and without this case (number 28, Table 1). Historical hospital records were not checked for the other cases.

Abdominal muscle contained generally less than $30 \mu \mathrm{g} / \mathrm{kg}$ mercury (median $3 \mu \mathrm{g} / \mathrm{kg}$ ). Both thyroid and pituitary contained considerably higher mercury concentrations; the median values were $19 \mu \mathrm{g} / \mathrm{kg}$ and $43 \mu \mathrm{g} / \mathrm{kg}$, respectively, and there was a considerable variation ranging to 1,000 and 2,900 $\mu \mathrm{g} / \mathrm{kg}$, respectively (Table 2). The highest median total-Hg concentration was found in toenails (median $236 \mu \mathrm{g} / \mathrm{kg}$ ), although the variation was small; the highest value being just 3.6 times higher than the median. Contrary to blood from vena femoralis, samples from heart blood were highly inhomogeneous due to extensive coagulation and we did not consider the con- 
Table I: Demographic data on the individuals included in the study.

\begin{tabular}{|c|c|c|c|c|c|c|}
\hline Case \# & Gender & Age (years) & Smoking status a & Alcohol abuse ${ }^{b}$ & Amalgam surfaces & Transfusion ${ }^{c}$ \\
\hline I & Male & 79 & CS & $Y$ & 0 & $Y$ \\
\hline 2 & Female & 78 & $N / A$ & $\mathrm{~N}$ & 6 & $\mathrm{~N}$ \\
\hline 3 & Male & 65 & CS & $\mathrm{N}$ & 4 & $Y$ \\
\hline 4 & Male & 73 & NS & $\mathrm{N}$ & 0 & $Y$ \\
\hline 5 & Male & 71 & CS & $\mathrm{N}$ & 5 & $Y$ \\
\hline 6 & Male & 48 & N/A & $\mathrm{N}$ & 43 & $\mathrm{~N}$ \\
\hline 7 & Male & 67 & FS & $\mathrm{N}$ & I & $\mathrm{N}$ \\
\hline 8 & Male & 63 & FS & $\mathrm{N}$ & 43 & $\mathrm{~N}$ \\
\hline 9 & Male & 61 & $N / A$ & $\mathrm{~N}$ & 13 & $\mathrm{~N}$ \\
\hline 10 & Female & 78 & CS & $\mathrm{N}$ & 11 & $\mathrm{~N}$ \\
\hline 11 & Male & 71 & CS & $Y$ & 0 & $Y$ \\
\hline 12 & Male & 90 & NS & $\mathrm{N}$ & 0 & $\mathrm{~N}$ \\
\hline 13 & Female & 70 & FS & $\mathrm{N}$ & 0 & $\mathrm{~N}$ \\
\hline 14 & Male & 78 & N/A & $\mathrm{N}$ & 0 & $\mathrm{~N}$ \\
\hline 15 & Male & 71 & CS & $\mathrm{N}$ & 2 & $Y$ \\
\hline 16 & Female & 63 & CS & $\mathrm{N}$ & 24 & $Y$ \\
\hline 17 & Female & 49 & NS & $\mathrm{N}$ & 42 & $\mathrm{~N}$ \\
\hline 18 & Male & 49 & CS & $\mathrm{N}$ & 29 & $Y$ \\
\hline 19 & Male & 71 & FS & $\mathrm{N}$ & 11 & $Y$ \\
\hline 20 & Male & 65 & $N / A$ & $\mathrm{~N}$ & 12 & $Y$ \\
\hline 21 & Male & 79 & CS & $\mathrm{N}$ & 0 & $\mathrm{~N}$ \\
\hline 22 & Male & 47 & $\mathrm{CS}$ & $\mathrm{N}$ & 0 & $\mathrm{~N}$ \\
\hline 23 & Female & 62 & FS & $\mathrm{N}$ & 5 & $\mathrm{~N}$ \\
\hline 24 & Female & 54 & N/A & $\mathrm{N}$ & 50 & $\mathrm{~N}$ \\
\hline 25 & Female & 78 & FS & $\mathrm{N}$ & 0 & $\mathrm{~N}$ \\
\hline 26 & Female & 64 & $N / A$ & $\mathrm{~N}$ & 24 & $\mathrm{~N}$ \\
\hline 27 & Female & 56 & NS & $\mathrm{N}$ & 24 & $\mathrm{~N}$ \\
\hline $28^{d}$ & Female & 91 & NS & $\mathrm{N}$ & 13 & $\mathrm{~N}$ \\
\hline 29 & Female & 83 & $N / A$ & $\mathrm{~N}$ & 0 & $\mathrm{~N}$ \\
\hline 30 & Female & 68 & N/A & $\mathrm{N}$ & 34 & $\mathrm{~N}$ \\
\hline
\end{tabular}

a) CS: Current smoker; FS: Former smoker; NS: Non smoker; N/A: Data not available

b) As noted in the hospital record (Yes/No)

c) Blood transfusion the last three months as noted in the hospital record (Yes/No)

d) Previous occupational exposure to mercury (retired dental nurse)

Table 2: Results from determinations of methylmercury, inorganic mercury and total mercury in tissues.

\begin{tabular}{|c|c|c|c|c|c|c|c|c|}
\hline Tissue & Analyte ${ }^{a}$ & Median & Mean b & SD & Min & Max & 10-percentile & 90-percentile \\
\hline \multirow[t]{3}{*}{ Blood (v. femoralis) ( $\mu \mathrm{g} / \mathrm{L})$} & $\mathrm{T}-\mathrm{Hg}$ & 3.3 & 5 & 5.3 & 0.9 & 27.4 & 1.4 & 12.5 \\
\hline & $\mathrm{I}-\mathrm{Hg}$ & 1.0 & 2.3 & 4.2 & 0.1 & 22.4 & 0.2 & 5.2 \\
\hline & $\mathrm{MeHg}$ & 2.2 & 2.7 & 2.3 & 0.3 & 10.9 & 0.9 & 6.2 \\
\hline \multirow[t]{3}{*}{ Occipital cortex $(\mu \mathrm{g} / \mathrm{kg})$} & $\mathrm{T}-\mathrm{Hg}$ & 12 & 18 & 32 & 1 & 181 & 5 & 28 \\
\hline & $\mathrm{I}-\mathrm{Hg}$ & 5 & 12 & 29 & 2 & 164 & 3 & 18 \\
\hline & $\mathrm{MeHg}$ & 4 & 6 & 6 & $<$ D.L.c & 28 & 1 & 16 \\
\hline Abdominal muscle $(\mu \mathrm{g} / \mathrm{kg})$ & $\mathrm{T}-\mathrm{Hg}$ & 3 & 5 & 6 & 0.3 & 29 & 0.9 & 12 \\
\hline Thyroid gland $(\mathrm{n}=28)(\mu \mathrm{g} / \mathrm{kg})$ & $\mathrm{T}-\mathrm{Hg}$ & 19 & 55 & 186 & 2.7 & 1000 & 5.1 & 47 \\
\hline Pituitary gland $(\mu \mathrm{g} / \mathrm{kg})$ & $\mathrm{T}-\mathrm{Hg}$ & 43 & 200 & 540 & 4.9 & 2900 & 12 & 460 \\
\hline Toenails $(n=29)(\mu g / k g)$ & $\mathrm{T}-\mathrm{Hg}$ & 236 & 280 & 214 & 64 & 856 & 67 & 624 \\
\hline
\end{tabular}

a) T-Hg: Total mercury concentration; I-Hg: Inorganic mercury concentration; MeHg: Methylmercury concentration

b) Samples with concentrations below detection limit were given a value of half the detection limit of the actual analytical run

c) Detection Limit 
centrations obtained in those samples as reliable. Thus, no data are presented for heart blood.

Correlational analyses (Table 3) showed a significant association between $\mathrm{MeHg}$ in blood and brain cortex (Figure 1). Further, significant correlations were found between total-Hg in toenails and MeHg in blood (correlation coefficient 0.634, n = 29, p < 0.001; Figure 1) and occipital lobe cortex (correlation coefficient $0.586, \mathrm{n}=29$, $\mathrm{p}=0.001 ;$ Figure 2).

There was a significant correlation between $\mathrm{I}-\mathrm{Hg}$ in blood and the number of surfaces filled with dental amalgam at time of death $(p=0.019$, Figure 3$)$. Inclusion of the data from case 28 (the retired dental nurse) did not change this finding (Table 3). Both I-Hg in blood and number of surfaces filled with dental amalgam decreased significantly with age (Table 3 ). An increase in age by 10 years (from 50 to 60 years of age) was associated with a decrease in number of surfaces filled with dental amalgam, from 28.0 to 19.8 at the age of 60 .

After exclusion of the retired dental nurse (case 28) the correlation coefficients between number of amalgam surfaces at time of death and concentration of I-Hg in occipital cortex, pituitary and thyroid were highly significant (Figure 3). The correlation coefficients were $0.55(\mathrm{p}=$ $0.002, \mathrm{n}=29), 0.54(\mathrm{p}=0.002, \mathrm{n}=29)$ and $0.53(\mathrm{p}=$ $0.004, \mathrm{n}=27$ ), respectively (Table 3 ). There was no significant association between I-Hg in blood and occipital lobe cortex $(r=-0.026, p=0.891, n=30$; Table 3 and Figure 4$)$. $\mathrm{I}-\mathrm{Hg}$ in occipital lobe cortex was significantly correlated with total mercury in thyroid and pituitary (Table 3, Figure 5 and 6 ).

Using the number of teeth filled with dental amalgam as a substitute for number of tooth surfaces filled with dental amalgam as estimate of amalgam exposure, similar results with only minor variations of the correlation coefficients were found. Nor was there any major change in the correlation coefficients when a more detailed measure of amalgam exposure ("amalgam points") [23] was used instead of number of surfaces filled with dental amalgam. The correlation coefficient between I-Hg in occipital lobe cortex and number of teeth filled with dental amalgam was $0.577(\mathrm{p}=0.001, \mathrm{n}=29)$ and the correlation coefficient between $\mathrm{I}-\mathrm{Hg}$ in occipital lobe cortex and "amalgam points" was $0.552(\mathrm{p}=0.002, \mathrm{n}=29)$.

Analysis by linear multiple regression (stepwise, backward) with I-Hg in brain cortex as dependent variable and number of surfaces filled with amalgam, age, gender, and $\mathrm{MeHg}$ in blood as independent variables (excluding case 28 with previous occupational exposure to mercury) showed a significant effect from exposure to amalgam res- torations ( $\mathrm{p}=0.002$, Table 4$)$. The regression coefficient of 0.153 (95\% confidence interval 0.061 to 0.245 ) indicated an average increase of about $1.5 \mu \mathrm{g} \mathrm{I-Hg} / \mathrm{kg}$ brain cortex for each 10 amalgam filled surfaces. The other independent variables (age, gender, and $\mathrm{MeHg}$ in blood) were not significant in the model (Table 4).

Similar regression models were used for analyses of total mercury in pituitary $(\mathrm{n}=29)$, thyroid $(\mathrm{n}=27)$ and toenail $(n=28)$. The results showed significant effects from number of surfaces filled with amalgam for the models for pituitary and thyroid. In the model for total-Hg in toenail, only MeHg in blood was significant (Table 4).

Results from the analytical quality control are given in Table 5. Scatterplots of data from determinations of $\mathrm{Hg}$ by CVAFS and ICP-SFMS in duplicate samples of blood and occipital cortex are shown in Figure 7.

\section{Discussion}

This study provides support to the importance of dental amalgam as a source of $\mathrm{I}-\mathrm{Hg}$ in both blood and brain. In addition, total-Hg concentration in pituitary and thyroid was strongly associated with the number of dental amalgam surfaces. However, there is no evidence from epidemiological studies that exposure to dental amalgam restorations is associated with disease, impaired neuropsychological functions or prevalence of general health complaints [24-29]. Nevertheless, an association between amalgam exposure and subclinical neurological effects have been reported [30], which may be consistent with an association between cumulative amalgam exposure and some neurological diagnoses as reported by Bates et al. [28].

Although the number of amalgam surfaces at the time of death do not reflect lifetime cumulative exposure to $\mathrm{Hg}^{0}$ or dental amalgam restorations, there was a significant correlation between amalgam surfaces at the time of death and concentration of I-Hg in brain at the time of death. This suggests that the biological half-time in the brain of the main fraction of $\mathrm{Hg}$ stored in brain after low level $\mathrm{Hg}^{0}$ exposure from dental amalgam restorations and other low level environmental sources is relatively short and that other environmental sources have limited importance at a group level.

As expected, we found a positive association between $\mathrm{MeHg}$ in blood and brain cortex. Interestingly, we also found a significant correlation between total mercury in toenail on the one hand and MeHg in blood and brain cortex on the other. The toenail clippings were collected from all toes, reflecting an integrated measure of incorporated mercury between 100 and 140 days before death, based on a mean toenail growth rate of $0.07 \mathrm{~mm} /$ day 


\begin{tabular}{|c|c|c|c|c|c|c|c|c|c|c|c|c|}
\hline & & $\begin{array}{c}\mathrm{I}-\mathrm{Hg} \\
\text { in blood }\end{array}$ & $\begin{array}{c}\mathrm{MeHg} \\
\text { in blood }\end{array}$ & $\begin{array}{c}\mathrm{I}-\mathrm{Hg} \text { in } \\
\text { occipital cortex }\end{array}$ & $\begin{array}{c}\text { MeHg in } \\
\text { occipital cortex }\end{array}$ & $\begin{array}{c}\mathrm{Hg} \text { in } \\
\text { occipital cortex }\end{array}$ & $\begin{array}{l}\mathrm{Hg} \text { in } \\
\text { pituitary }\end{array}$ & $\begin{array}{l}\mathrm{Hg} \text { in } \\
\text { thyroid }\end{array}$ & $\begin{array}{l}\mathrm{Hg} \text { in } \\
\text { toenail }\end{array}$ & $\begin{array}{c}\mathrm{Hg} \text { in } \\
\text { abdominal muscle }\end{array}$ & Age & $\begin{array}{c}\text { Filled } \\
\text { surfaces - amalgam }\end{array}$ \\
\hline \multirow[t]{3}{*}{$\mathrm{I}-\mathrm{Hg}$ in blood } & Correlation & & 0.251 & -0.026 & 0.052 & 0.006 & -0.062 & -0.039 & 0.065 & -0.045 & -0.402 & 0.432 \\
\hline & Sig. (2-tailed) & & 0.181 & 0.891 & 0.784 & 0.974 & 0.744 & 0.845 & 0.738 & 0.815 & 0.028 & 0.017 \\
\hline & $\mathrm{N}$ & & 30 & 30 & 30 & 30 & 30 & 28 & 29 & 30 & 30 & 30 \\
\hline \multirow[t]{3}{*}{$\mathrm{MeHg}$ in blood } & Correlation & 0.246 & & -0.071 & 0.725 & 0.232 & -0.107 & -0.090 & 0.634 & 0.230 & 0.055 & -0.126 \\
\hline & Sig. (2-tailed) & 0.198 & & 0.710 & $<0.001$ & 0.218 & 0.572 & 0.648 & $<0.001$ & 0.221 & 0.774 & 0.507 \\
\hline & $N$ & 29 & & 30 & 30 & 30 & 30 & 28 & 29 & 30 & 30 & 30 \\
\hline \multirow[t]{3}{*}{$\mathrm{I}-\mathrm{Hg}$ in occipital cortex } & Correlation & 0.253 & 0.134 & & 0.339 & 0.927 & 0.967 & 0.993 & -0.086 & -0.155 & 0.334 & 0.081 \\
\hline & Sig. (2-tailed) & 0.186 & 0.490 & & 0.067 & $<0.001$ & $<0.001$ & $<0.001$ & 0.656 & 0.414 & 0.071 & 0.669 \\
\hline & $\mathrm{N}$ & 29 & 29 & & 30 & 30 & 30 & 28 & 29 & 30 & 30 & 30 \\
\hline \multirow[t]{3}{*}{ MeHg in occipital cortex } & Correlation & 0.079 & 0.804 & 0.081 & & 0.617 & 0.287 & 0.336 & 0.586 & 0.258 & 0.154 & -0.136 \\
\hline & Sig. (2-tailed) & 0.686 & $<0.001$ & 0.677 & & $<0.001$ & 0.124 & 0.081 & 0.001 & 0.169 & 0.416 & 0.472 \\
\hline & $\mathrm{N}$ & 29 & 29 & 29 & & 30 & 30 & 28 & 29 & 30 & 30 & 30 \\
\hline $\mathrm{Hg}$ in & Correlation & 0.147 & 0.713 & 0.604 & 0.768 & & 0.904 & 0.910 & 0.154 & -0.048 & 0.295 & 0.080 \\
\hline \multirow[t]{2}{*}{ occipital cortex } & Sig. (2-tailed) & 0.447 & $<0.001$ & 0.001 & $<0.001$ & & $<0.001$ & $<0.001$ & 0.425 & 0.800 & 0.113 & 0.676 \\
\hline & $\mathrm{N}$ & 29 & 29 & 29 & 29 & & 30 & 28 & 29 & 30 & 30 & 30 \\
\hline \multirow[t]{3}{*}{$\mathrm{Hg}$ in pituitary } & Correlation & -0.002 & -0.062 & 0.652 & -0.086 & 0.390 & & 0.953 & -0.100 & -0.149 & 0.261 & 0.173 \\
\hline & Sig. (2-tailed) & 0.993 & 0.748 & $<0.001$ & 0.659 & 0.036 & & $<0.001$ & 0.607 & 0.432 & 0.163 & 0.360 \\
\hline & $\mathrm{N}$ & 29 & 29 & 29 & 29 & 29 & & 28 & 29 & 30 & 30 & 30 \\
\hline \multirow[t]{3}{*}{$\mathrm{Hg}$ in thyroid } & Correlation & 0.352 & 0.142 & 0.602 & 0.105 & 0.396 & 0.402 & & -0.087 & -0.125 & 0.351 & 0.031 \\
\hline & Sig. (2-tailed) & 0.072 & 0.479 & 0.001 & 0.603 & $0.04 I$ & 0.038 & & 0.667 & 0.525 & 0.067 & 0.875 \\
\hline & $\mathrm{N}$ & 27 & 27 & 27 & 27 & 27 & 27 & & 27 & 28 & 28 & 28 \\
\hline \multirow[t]{3}{*}{$\mathrm{Hg}$ in toenail } & Correlation & 0.060 & 0.631 & -0.093 & 0.649 & 0.525 & -0.095 & -0.091 & & 0.139 & 0.158 & -0.328 \\
\hline & Sig. (2-tailed) & 0.760 & $<0.001$ & 0.638 & $<0.001$ & 0.004 & 0.629 & 0.660 & & 0.472 & 0.414 & 0.083 \\
\hline & $\mathrm{N}$ & 28 & 28 & 28 & 28 & 28 & 28 & 26 & & 29 & 29 & 29 \\
\hline \multirow[t]{3}{*}{$\mathrm{Hg}$ in abdominal muscle } & Correlation & -0.055 & 0.220 & -0.079 & 0.328 & 0.186 & -0.038 & 0.335 & 0.130 & & -0.003 & -0.081 \\
\hline & Sig. (2-tailed) & 0.778 & 0.251 & 0.683 & 0.083 & 0.334 & 0.847 & 0.088 & 0.510 & & 0.988 & 0.672 \\
\hline & $\mathrm{N}$ & 29 & 29 & 29 & 29 & 29 & 29 & 27 & 28 & & 30 & 30 \\
\hline \multirow[t]{3}{*}{ Age } & Correlation & -0.408 & 0.096 & -0.208 & 0.037 & -0.084 & -0.287 & -0.215 & 0.200 & 0.055 & & -0.610 \\
\hline & Sig. (2-tailed) & 0.028 & 0.621 & 0.278 & 0.849 & 0.664 & 0.131 & 0.282 & 0.308 & 0.778 & & $<0.001$ \\
\hline & $\mathrm{N}$ & 29 & 29 & 29 & 29 & 29 & 29 & 27 & 28 & 29 & & 30 \\
\hline \multirow[t]{3}{*}{ Filled surfaces - amalgam } & Correlation & 0.433 & -0.127 & 0.550 & -0.144 & 0.185 & $0.54 I$ & 0.530 & -0.328 & -0.082 & -0.655 & \\
\hline & Sig. (2-tailed) & 0.019 & 0.513 & 0.002 & 0.457 & 0.337 & 0.002 & 0.004 & 0.088 & 0.673 & $<0.001$ & \\
\hline & $N$ & 29 & 29 & 29 & 29 & 29 & 29 & 27 & 28 & 29 & 29 & \\
\hline
\end{tabular}



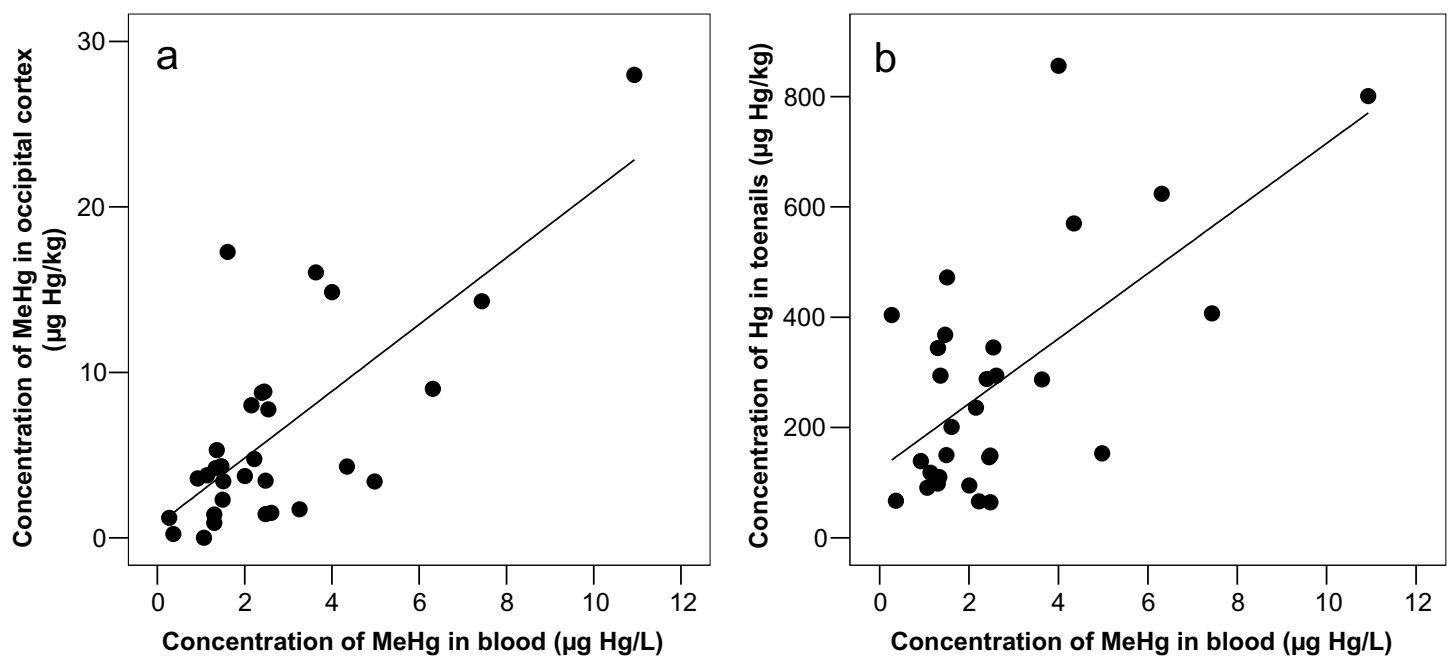

\section{Figure I}

Methylmercury in blood related to concentration of methylmercury in brain and total-Hg in toenails. Concentration of methylmercury in blood $\left(\mathrm{C}_{\text {MeHg-Blood; } \mu \mathrm{g} \mathrm{Hg} / \mathrm{L}}\right)$ related to concentration of (a) methylmercury in occipital lobe cortex $\left(\mathrm{C}_{\mathrm{MeHg}-\mathrm{Brain} ; \mu \mathrm{g} \mathrm{Hg} / \mathrm{kg}}\right)$ and $(\mathrm{b})$ concentration of total- $\mathrm{Hg}$ in toenails $\left(\mathrm{C}_{\mathrm{Hg} \text {-Toenail; } \mu \mathrm{g} \mathrm{Hg} / \mathrm{kg}}\right)$. The equations for the regression lines were (a) $\mathrm{C}_{\mathrm{MeHg} \text {-Brain }}=2.0 \times \mathrm{C}_{\mathrm{MeHg} \text {-blood }}+0.8$, (correlation coefficient $0.725, \mathrm{n}=30, \mathrm{p}<0.00 \mathrm{I}$ ) and (b) $\mathrm{C}_{\mathrm{Hg} \text {-toenail }}=59 \times \mathrm{C}_{\mathrm{MeHg} \text {-Blood }}+$ 125, (correlation coefficient $0.634, n=29, p<0.001$ ).

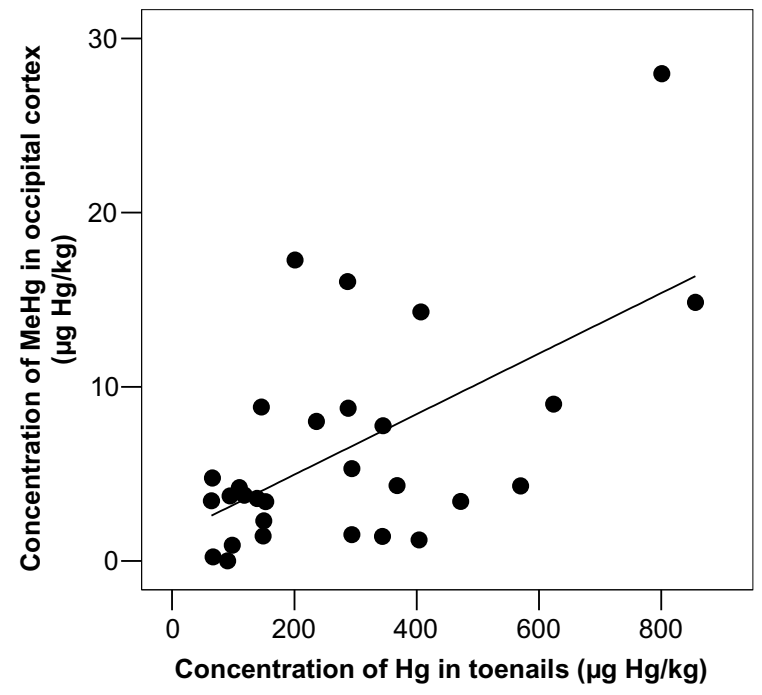

Figure 2

Concentration of methylmercury in brain related to concentration of total- $\mathrm{Hg}$ in toenails. Concentration of methylmercury in occipital lobe cortex $\left(\mathrm{C}_{\mathrm{MeHg}-\mathrm{Brain} ; \mu \mathrm{g} \mathrm{Hg} / \mathrm{kg}}\right)$ related to concentration of total- $\mathrm{Hg}$ in toenails $\left(\mathrm{C}_{\mathrm{Hg} \text {-Toenail; } \mu \mathrm{g}}\right.$ $\mathrm{Hg} / \mathrm{kg})$. The equation for the regression line was $\mathrm{C}_{\mathrm{MeHg} \text {-Brain }}=$ $0.017 \times \mathrm{C}_{\mathrm{Hg} \text {-toenail }}+\mathrm{I} .5$, and the correlation coefficient was $0.586(n=29, p=0.001)$.
[31]. Thus, toenail clippings of about $1 \mathrm{~mm}$ would more closely reflect blood levels at a time window of about two weeks; 3 to 5 months prior to the clipping, and the correlation should be interpreted with this in mind. Toenail mercury has, like hair mercury, been used in several studies as indicator of exposure and in order to get a better understanding of the relations between $\mathrm{MeHg}$ exposure and in MeHg in blood and toenail the lag time should be considered. There was no significant association between total mercury in toenail and $\mathrm{I}-\mathrm{Hg}$, which fits with the assumption that mercury in toenails, like that in hair [14], is likely to be almost exclusively MeHg. Thus, total mercury in toenails may be an indicator of $\mathrm{MeHg}$ stored in the body, and may be a useful complement to mercury in hair for $\mathrm{MeHg}$ exposure assessment [32]. The ratio of total $\mathrm{Hg}$ in nail to MeHg in blood was about 100, which is less than one third of the hair to blood ratio [14].

A small fraction of $\mathrm{MeHg}$ in the brain demethylates to inorganic mercury, which is retained for very long times, especially in pituitary and thalamus [33], probably mainly due to association with selenium to highly insoluble mercury selenide [34]. Consequently, a fraction of the inorganic mercury in brain could be related to past exposure to MeHg. Possibly, the absence of an increase in $\mathrm{I}-\mathrm{Hg}$ in occipital cortex by age was due to the relatively low exposure to methylmercury in this population $[35,36]$. Because of the relatively low $\mathrm{MeHg}$ exposure the $\mathrm{MeHg}$ 

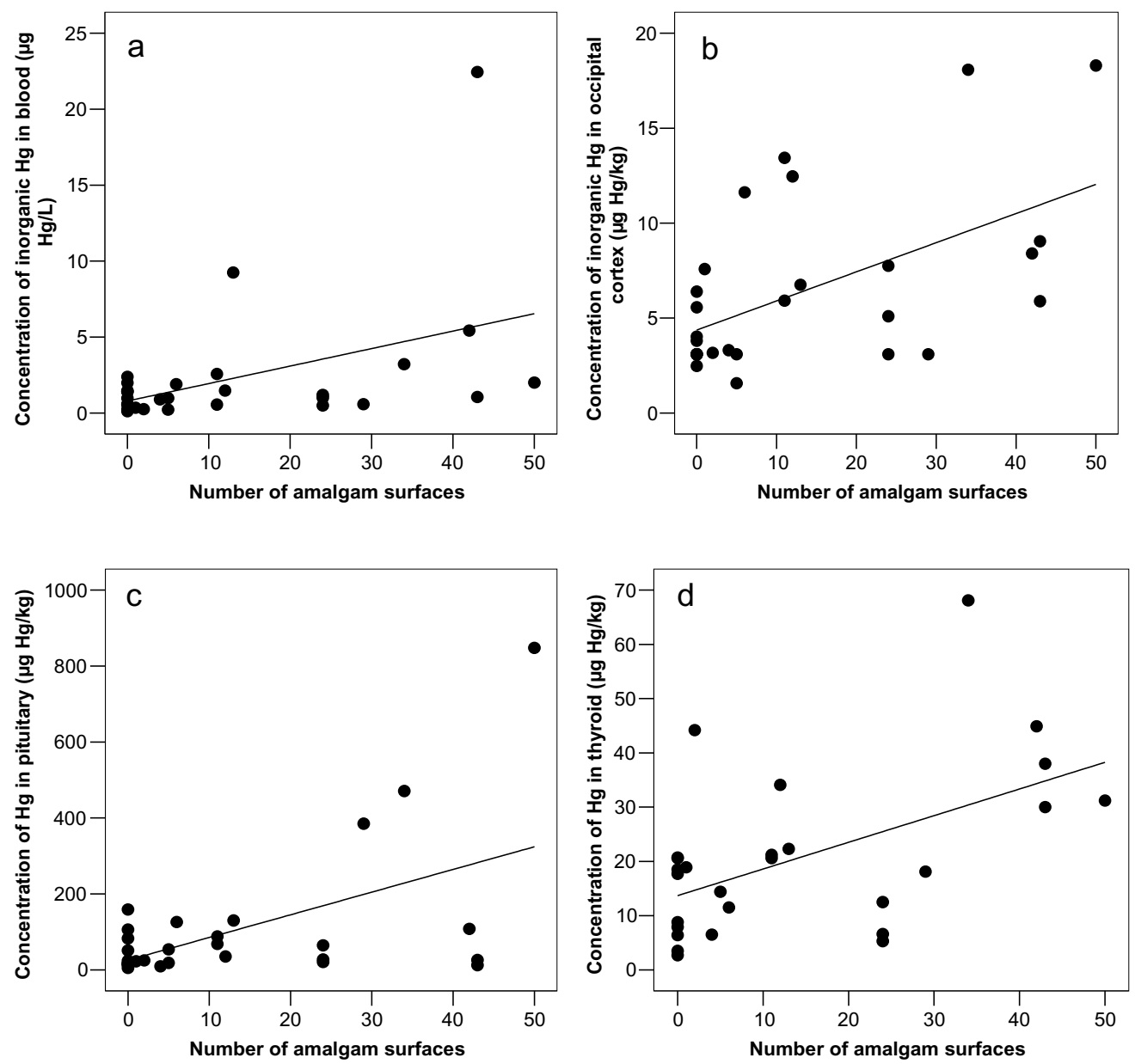

\section{Figure 3}

Amalgam surfaces related to $\mathbf{~}-\mathrm{Hg}$ in blood and brain, and total- $\mathbf{H g}$ in pituitary and thyroid. Number of amalgam surfaces related to concentration of (a) inorganic $\mathrm{Hg}$ in blood $\left(\mathrm{C}_{\mathrm{l}-\mathrm{Hg} \text {-Blood; } \mu \mathrm{g} \mathrm{Hg/L}}\right)$, (b) inorganic $\mathrm{Hg}$ in occipital cortex $\left(\mathrm{C}_{\mathrm{l}-\mathrm{Hg} \text {-Brain; }}\right.$ $\mu \mathrm{g} \mathrm{Hg} / \mathrm{kg})$, (c) total- $\mathrm{Hg}$ in pituitary $\left(\mathrm{C}_{\text {Pituitary; } \mu \mathrm{g} \mathrm{Hg} / \mathrm{kg}}\right)$ and $(\mathrm{d})$ total- $\mathrm{Hg}$ in thyroid $\left(\mathrm{C}_{\text {Thyroid; } \mu \mathrm{g} \mathrm{Hg} / \mathrm{kg}}\right)$. The equations for the regression lines were (a) $C_{1-H g-B l o o d}=0.12 \times$ [number of amalgam surfaces] +0.79 , (correlation coefficient $0.433, n=29, p=0.019$ ), (b) $C_{1-}$ $\mathrm{Hg}$-Brain $=0.15 \times$ [number of amalgam surfaces] +4.4 , (correlation coefficient $0.550, \mathrm{n}=29, \mathrm{p}=0.002$ ), (c) $\mathrm{C}_{\mathrm{Pituitary}}=6.0 \times$ [number of amalgam surfaces] +25.5 , (correlation coefficient $0.541, n=29, p=0.002$ ), and $(d) C_{\text {Thyroid }}=0.49 \times$ [number of amalgam surfaces] + 13.7, (correlation coefficient $0.530, n=27, p=0.004$ ).

level in blood was low, and consequently the MeHg/total$\mathrm{Hg}$ ratio in blood was low compared with populations with high exposure to $\mathrm{MeHg}$ and low exposure to I-Hg [37]. However, there was a wide variation in the individual $\mathrm{MeHg} /$ total-Hg ratio in blood indicating that the group was heterogeneous with regard to $\mathrm{MeHg}$ exposure, fish intake and exposure to $\mathrm{I}-\mathrm{Hg}$.

It is well known that drugs may be redistributed within hours after death, which may result in erroneous post mortem values in blood [38]. In the present study, the median concentration of total-Hg in blood was similar to levels found in Norwegian populations $[39,40]$. Thus, the use of blood from vena femoralis collected post mortem is likely a useful medium for monitoring recent exposure to mercury. The samples of blood from the heart were not homogenous and could not be used to evaluate possible post mortal redistributions of mercury.

Despite the fact that the concentrations of I-Hg in both blood and brain cortex were significantly correlated with the number of dental surfaces with amalgam fillings, there was no significant correlation between I-Hg in blood and brain cortex (Table 3 and Figure 4). This may be explained 


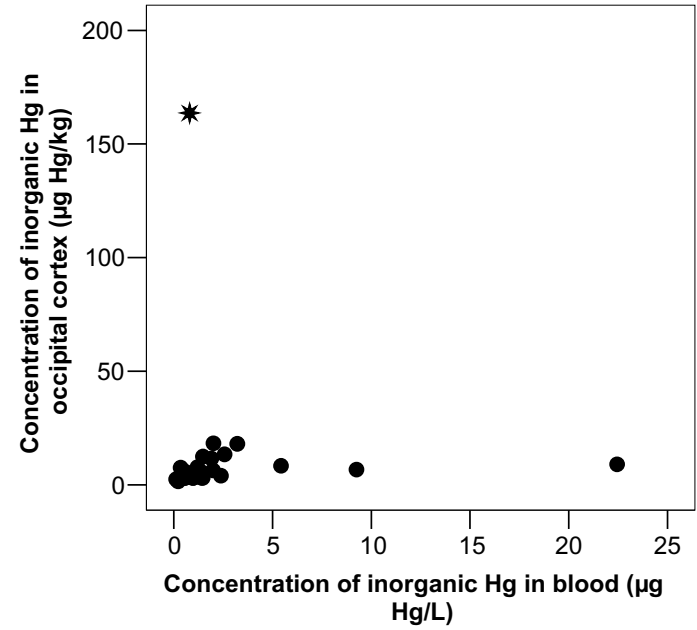

Figure 4

$\mathrm{I}-\mathrm{Hg}$ in brain related to $\mathbf{I - H g}$ blood. Concentration of inorganic $\mathrm{Hg}$ in occipital cortex related to concentration of inorganic $\mathrm{Hg}$ blood. The correlation coefficient was not significant $(r=-0.026, p=0.891, n=30)$. When the dental nurse (case 28 , denoted with $\%$ in the Figure) was excluded, the correlation coefficient was $0.253(p=0.186, n=29)$.

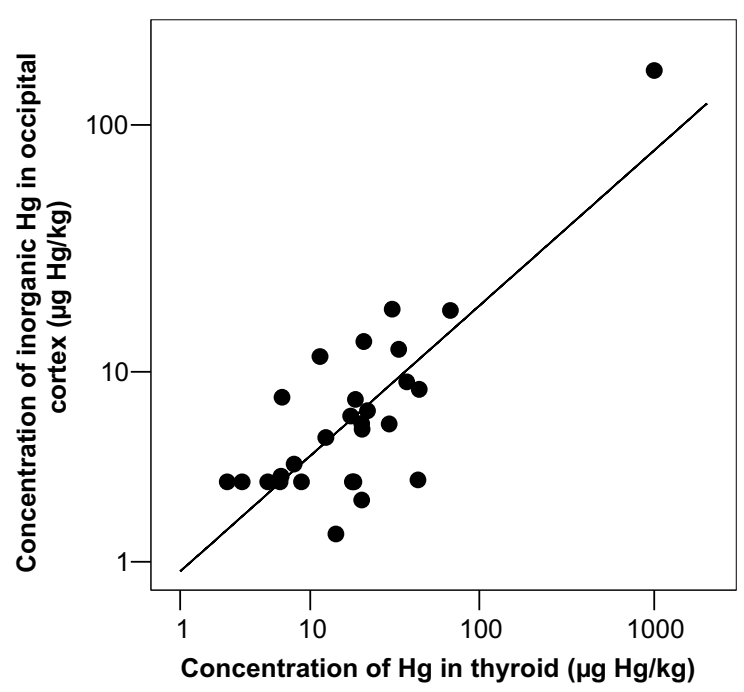

Figure 5

$\mathrm{I-Hg}$ in brain related to concentration of total-Hg in thyroid. Concentration of inorganic $\mathrm{Hg}$ in occipital cortex related to concentration of total- $\mathrm{Hg}$ in thyroid gland. The correlation coefficient of the $\log _{10}$ transformed values was $0.769(n=28, p<0.00 I)$.

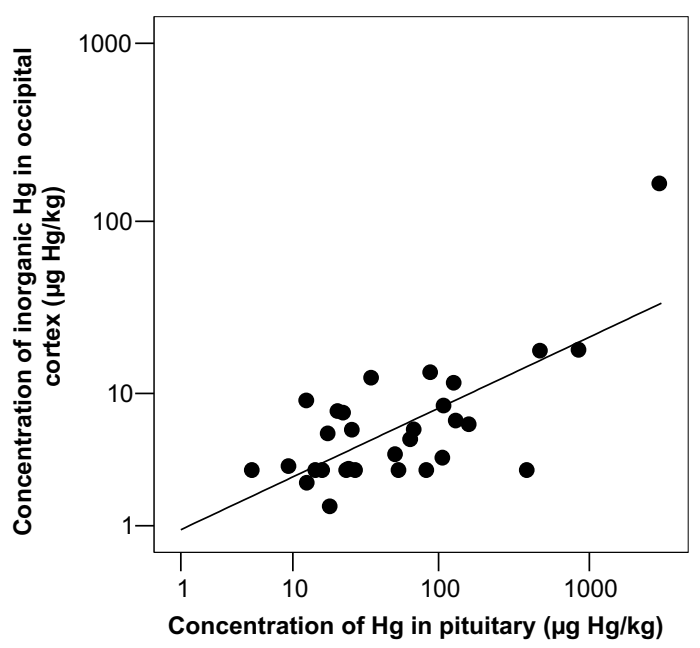

Figure 6

$\mathrm{I-Hg}$ in brain related to total-Hg in pituitary. Concentration of inorganic $\mathrm{Hg}$ in occipital cortex related to concentration of total- $\mathrm{Hg}$ in pituitary. The correlation coefficient of the $\log _{10}$ transformed values was $0.693(n=30, p<0.001)$.

by the differences in toxicokinetics between elemental mercury $\left(\mathrm{Hg}^{0}\right)$ and oxidized mercury. Although elemental mercury is rapidly oxidized by catalase in the blood to mercuric mercury $\left(\mathrm{Hg}^{2+}\right)$, a substantial fraction of the inhaled elemental mercury will pass the blood brain barrier before being oxidized. Probably, most of the mercury vapor is then oxidized to mercuric mercury $\left(\mathrm{Hg}^{2+}\right)$ in the brain. Mercuric mercury does not pass the blood brain barrier and, consequently, it is not distributed as such into the brain. Amalgam fillings not only release elemental mercury vapor, but they also corrode and release corrosion products [41]. These corrosion products contain mercuric mercury and other metals (e.g. silver), which are swallowed and partly absorbed in the GI tract into blood [42]. Individual variation in exposure to corrosion products released from amalgam fillings may contribute to the lack of correlation between inorganic $\mathrm{Hg}$ in blood and inorganic $\mathrm{Hg}$ in brain in addition to the differences in toxicokinetics of I-Hg in blood and brain.

One individual (case 6 ) had a relatively high $\mathrm{I}-\mathrm{Hg}$ in blood $(22.4 \mu \mathrm{g} / \mathrm{L})$, constituting about $82 \%$ of the total blood $\mathrm{Hg}$. This individual had a high number of dental amalgam restorations (43 amalgam surfaces), but there were no obvious signs of bruxism or intense chewing which could explain the high level of I-Hg in blood [43]. In conflict with the high level of $\mathrm{I}-\mathrm{Hg}$ in blood, the concentration of I-Hg in brain of this case $(9 \mu \mathrm{g} / \mathrm{kg})$ was in the same range as for the rest of the group without previous 
Table 4: Results from linear multiple regression analyses. ${ }^{a}$

\begin{tabular}{|c|c|c|c|c|c|c|c|c|}
\hline \multirow[t]{2}{*}{ Dependent variable } & \multirow[t]{2}{*}{$\begin{array}{l}\text { Independent variable(s) } \\
\text { in the final model }\end{array}$} & \multicolumn{2}{|c|}{$\begin{array}{l}\text { Unstandardized } \\
\text { Coefficients }\end{array}$} & \multirow{2}{*}{$\frac{\begin{array}{c}\text { Standardized } \\
\text { Coefficients }\end{array}}{\text { Beta }}$} & \multirow[t]{2}{*}{$\mathrm{t}$} & \multirow[t]{2}{*}{ Sig. } & \multicolumn{2}{|c|}{$95 \%$ Confidence Interval for B } \\
\hline & & B & Std. Error & & & & Lower Bound & Upper Bound \\
\hline \multirow[t]{2}{*}{ a) $\mathrm{I}-\mathrm{Hg}$ in brain cortex } & Constant & 4.366 & 0.925 & & 4.720 & $<0.001$ & 2.468 & 6.264 \\
\hline & Filled surfaces - amalgam & 0.153 & 0.045 & 0.550 & 3.423 & 0.002 & 0.061 & 0.245 \\
\hline \multirow[t]{2}{*}{ b) Total-Hg in pituitary } & Constant & 25.540 & 36.893 & & 0.692 & 0.495 & -50.158 & 101.238 \\
\hline & Filled surfaces - amalgam & 5.972 & 1.788 & 0.541 & 3.340 & 0.002 & 2.304 & 9.640 \\
\hline \multirow[t]{2}{*}{ c) Total-Hg in thyroid } & Constant & 13.682 & 3.359 & & 4.073 & $<0.001$ & 6.763 & 20.601 \\
\hline & Filled surfaces - amalgam & 0.491 & 0.157 & 0.530 & 3.126 & 0.004 & 0.168 & 0.815 \\
\hline \multirow[t]{2}{*}{ d) Total- $\mathrm{Hg}$ in toenails } & Constant & 126.115 & 50.564 & & 2.494 & .019 & 22.180 & 230.051 \\
\hline & $\mathrm{MeHg}$ in blood $(\mu \mathrm{g} / \mathrm{L})$ & 58.888 & 14.190 & 0.631 & 4.150 & $<0.001$ & 29.720 & 88.056 \\
\hline
\end{tabular}

a Final results from linear multiple regression analyses using number of surfaces filled with amalgam, age, gender, and MeHg in blood as independent variables (all variables entered at the first step, and removed in the following step(s) if the p-value of the variable was $\geq 0.10$ ) and (a) I- $\mathrm{Hg}$ in brain cortex $(\mu \mathrm{g} \mathrm{l}-\mathrm{Hg} / \mathrm{kg})$ as dependent variable, (b) Total- $\mathrm{Hg}$ in pituitary $(\mu \mathrm{g} \mathrm{Hg} / \mathrm{kg})$ as dependent variable, (c) Total- $\mathrm{Hg}$ in thyroid $(\mu \mathrm{g} \mathrm{Hg} / \mathrm{kg})$ as dependent variable and (d) Total- $\mathrm{Hg}$ in toenails ( $\mu \mathrm{g} \mathrm{Hg} / \mathrm{kg}$ ) as dependent variable. The case with previous occupational exposure to mercury (case 28 ) was excluded from the regression analyses (see text). $N=29$ in model (a) and (b), $n=27$ in model (c) and $n=28$ in model (d).

occupational exposure to mercury. An explanation could be that the corrosion rate of the amalgam restorations was elevated and thus, the gastrointestinal exposure to amalgam corrosion products was higher than normal, although the exposure to mercury vapor derived from amalgam restorations was in the normal range. This was the only case from the Department for Forensic medicine, and another possibility is that movement of the body after death may have influenced post mortem redistribution of mercury [38].
There was a significant correlation between I-Hg in brain cortex and the number of amalgam surfaces, but only 30 $\%$ of the variance was explained by the regression model (Figure 3; $r=0.55, r^{2}=0.30$ ). This may in part be due to variations between individuals regarding release rate of mercury vapor from dental amalgam, and the toxicokinetic variations between individuals with regard to elemental mercury vapor $[8,10,44,45]$. Further, additional variation could be due to demethylated $\mathrm{Hg}$ derived from $\mathrm{MeHg}$ in the brain [33]. A possible effect from variations in selenium status on I-Hg in brain needs further analyses.

Table 5: Results from the analytical quality control

\begin{tabular}{|c|c|c|c|c|c|c|}
\hline \multirow[b]{2}{*}{ Material } & \multirow[b]{2}{*}{ Analyte ${ }^{a}$} & \multicolumn{4}{|c|}{ Concentrations found } & \multirow[b]{2}{*}{ Recommended (or certified) values } \\
\hline & & Mean & SD & $\mathrm{N}$ & Method & \\
\hline \multirow[t]{3}{*}{ LUTS-I; ng/g } & $\mathrm{T}-\mathrm{Hg}$ & 16.1 & - & I & CVAFS & $19.98(0.20) b$ \\
\hline & $\mathrm{I}-\mathrm{Hg}$ & 14.1 & - & I & CVAFS & - \\
\hline & $\mathrm{MeHg} d$ & 2.0 & - & I & CVAFS & $2.50(0.2 \mathrm{I})^{b}$ \\
\hline LUTS-I; ng/g & $\mathrm{MeHg} d$ & 2.7 & - & I & GC-ICPMS & $2.50(0.21)^{b}$ \\
\hline \multirow[t]{3}{*}{ Seronorm 404I07X; $\mu g / L$} & $\mathrm{~T}-\mathrm{Hg}$ & 2.5 & 0.14 & 3 & CVAFS & $3(2.2-3.3) c$ \\
\hline & $\mathrm{I}-\mathrm{Hg}$ & 0.5 & 0.03 & 3 & CVAFS & - \\
\hline & $\mathrm{MeHg} d$ & 2.0 & 0.13 & 3 & CVAFS & - \\
\hline \multirow[t]{3}{*}{ Seronorm 404I 08; $\mu \mathrm{g} / \mathrm{L}$} & $\mathrm{T}-\mathrm{Hg}$ & 8.5 & 0.74 & 4 & CVAFS & $8(6.7-8.4) c$ \\
\hline & $\mathrm{I}-\mathrm{Hg}$ & 6.3 & 0.18 & 4 & CVAFS & - \\
\hline & $\mathrm{MeHg}^{\mathrm{d}}$ & 2.2 & 0.68 & 4 & CVAFS & - \\
\hline LUTS-I; ng/g & $\mathrm{T}-\mathrm{Hg}$ & 19.9 & 1.19 & 12 & ICP-SFMS & $19.98(0.20)^{b}$ \\
\hline SRM 84I4; ng/g & $\mathrm{T}-\mathrm{Hg}$ & 5.5 & 0.63 & 8 & ICP-SFMS & $5 \pm 3^{e}$ \\
\hline SRM I577a; ng/g & $\mathrm{T}-\mathrm{Hg}$ & 3.6 & 0.51 & 8 & ICP-SFMS & $4 \pm 2^{e}$ \\
\hline
\end{tabular}

a) T-Hg: Total mercury concentration; $\mathrm{I}-\mathrm{Hg}$ : Inorganic mercury concentration; MeHg: Methylmercury concentration

b) Mean and one standard deviation, $\mathrm{n}=4$ for $\mathrm{Hg}$ and $\mathrm{n}=5$ for $\mathrm{MeHg}$ (Revised value by February 14, 2005; written personal communication, Dr.

Ralph Sturgeon, National Research Council of Canada/Institute for National Measurement Standards). Values from the certificate, revised in August

1995, were 16.7 for $\mathrm{T}-\mathrm{Hg}$ and 9.4 for $\mathrm{MeHg}$ with 95 percent confidence limits of 2.2 and 0.6 , respectively.

c) Recommended value (range)

d) as $\mathrm{Hg}$

e) Estimated uncertainties 

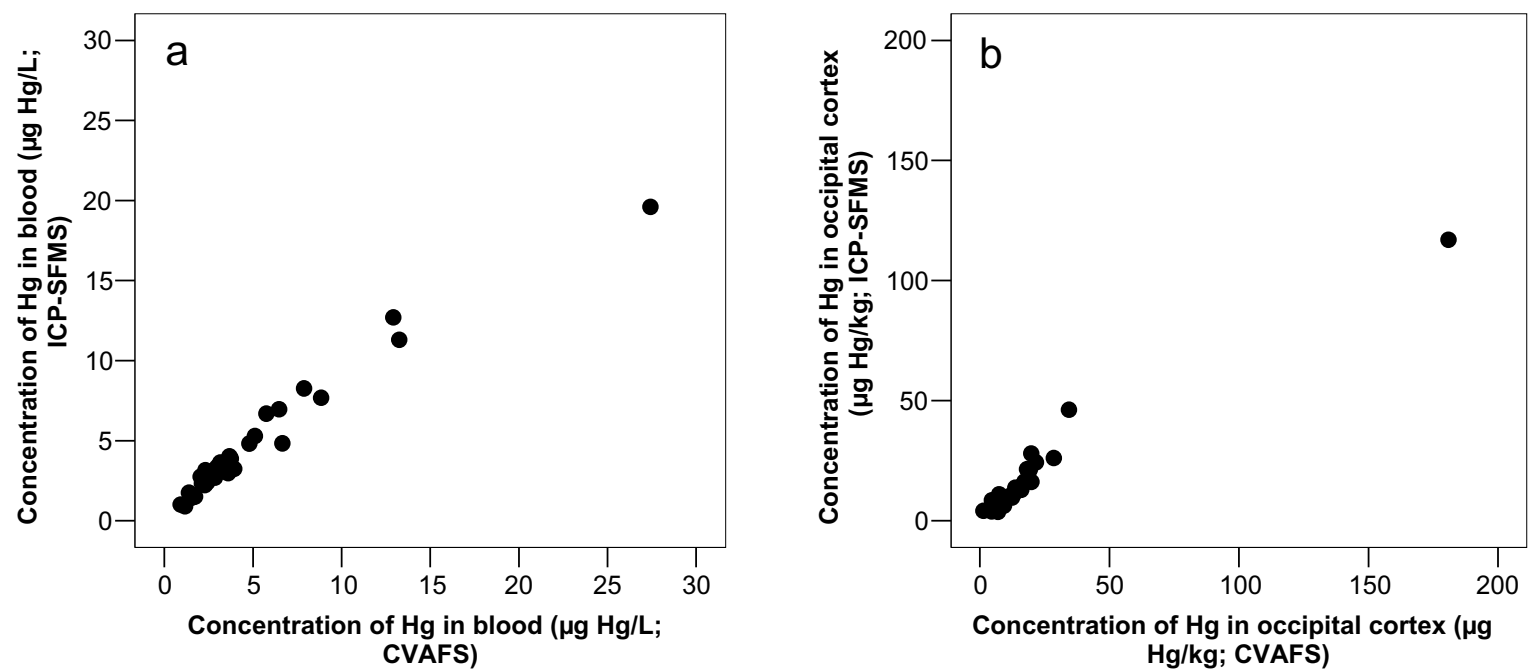

\section{Figure 7}

Determinations of total-Hg by ICP-SFMS related to determinations of total-Hg by CVAFS. Data from determinations of total-Hg by ICP-SFMS related to determinations of total-Hg by CVAFS in duplicate samples of blood (a) and occipital cortex (b). Correlation coefficients were $0.979(n=30)$ and $0.971(n=30)$, respectively.

We found one case with considerably higher brain inorganic mercury concentration than the others. Although, occupational exposure to mercury was an exclusion criterium, when the study was designed, it was first when we carefully examined the historical hospital records that we found out that this case was a retired dental nurse. She was the oldest individual in the study group and had probably been working as a dental assistant at times when the mercury exposure in dental clinics in Norway was considerably higher than today [46]. As the exposure to mercury in dental personnel in Norway was relatively high in the 1960ies, with reported median concentration of mercury in urine among dental nurses of $32 \mu \mathrm{g} / \mathrm{L}$ urine $(160 \mathrm{nmol} /$ $\mathrm{L})$ with a range from $1.5 \mu \mathrm{g} / \mathrm{L}$ to $620 \mu \mathrm{g} / \mathrm{L}(7.5$ to 3100 nmol/L) [47], exclusion of this case was justified.

It is well known that occupational exposure to high concentrations of mercury vapor can result in high levels of mercury in brain and other tissues several decades after the cessation of the exposure [48-50], indicating long half-times for inorganic mercury stored in the brain after exposure to high levels of mercury vapor. However, in conflict with data reported by Weiner and Nylander [51] the regression model analyzing the effects from amalgam surfaces, age, gender, and MeHg in blood on the concentrations of I-Hg in brain (excluding the dental nurse; Table 4) showed no significant influence by age, suggesting that the major fraction of mercury derived from amalgam restorations has a relatively short half-time in brain. However, the statistical power was too low to exclude a minor effect from age. The observations of high levels of I-Hg in brain several years after the cessation of occupational exposure to high levels of mercury vapor, but no significant effect from age in the regression analysis (Table 4), suggests that the kinetics of $\mathrm{I}-\mathrm{Hg}$ stored in brain after exposure to mercury vapor may be dose dependent with an induction of an alternative pathway for deposition of $\mathrm{I}-\mathrm{Hg}$ in the brain. One hypothesis is that when the exposure to mercury vapor is low, $\mathrm{Hg}$ is bound to sites with low total capacity, but with higher affinity than to a proposed selenium metabolite forming highly insoluble HgSe with long biological half-time in the brain (see above) [52]. Alternatively, there is a mercury induced selenium dependent mechanism resulting in a formation of highly insoluble mercury selenide which could explain the observations.

The concentrations of total mercury in occipital cortex found in the remaining cases, without known occupational exposure to mercury, were similar to the concentrations of total mercury earlier reported for deceased individuals without occupational exposure to mercury [9], but lower than those reported by Saxe et al [53]. A significant correlation between mercury in brain and number of surfaces filled with amalgam is reported previously [9]. However, Saxe et al [53] found no significant correlation between exposure to dental amalgam and total mercury in brain, which may be due to the impact from $\mathrm{MeHg}$ in the diet, which not was considered.

It is previously reported that mercury is stored in the pituitary of dental personnel [49]. In the present study signif- 
icant correlations between number of surfaces filled with amalgam and mercury concentrations in pituitary and thyroid. Probably, mercury is stored together with selenium in these tissues, resulting in very long biological half times [54]. High concentrations of $\mathrm{I}-\mathrm{Hg}$ in pituitary were also reported after experimental exposure of monkeys to $\mathrm{MeHg}$ [33] and there was some evidence for a co-accumulation of I-Hg with selenium [55].

There were no significant correlations between mercury concentration in abdominal muscle and mercury concentration in any of the other tissues, and the hypothesis that muscle biopsy could be used to predict mercury concentrations in the brain [56] was not supported.

The quality control of the mercury analyses indicated acceptable results. The problems with the stability of $\mathrm{MeHg}$ in reference materials stored for long times [57] was illustrated with the results from the analyses of the reference material LUTS-1. Obviously, there was a break down of $\mathrm{MeHg}$ to $\mathrm{I}-\mathrm{Hg}$ over time, resulting in a significant decrease of $\mathrm{MeHg}$ in the reference material without a decrease of total-Hg in the sample. Consequently, $\mathrm{Hg}$ and MeHg were removed from the certificate of LUTS- 1 in the revision of January 2005 [58].

\section{Conclusion}

In a fish-eating population, $\mathrm{MeHg}$ from the diet has a marked impact on total mercury concentration in the brain. Discrimination between mercury species is thus necessary to evaluate impact of dental amalgam exposure as well as fish consumption on $\mathrm{Hg}$ concentrations in the brain.

$\mathrm{MeHg}$ in blood is a useful marker for MeHg in brain. Total-Hg in toenails is a convenient and useful biomarker for MeHg in brain.

There were no useful biomarkers for I-Hg in the brain, but for individuals without occupational exposure to mercury, the number of tooth surfaces filled with amalgam was an indicator of concentration of I-Hg in brain at time of death, and a useful exposure indicator at a group level.

\section{Abbreviations \\ $\mathrm{CH}_{3} \mathrm{Hg}^{+}$Methylmercury}

CVAFS Cold vapor atomic fluorescence spectrophotometry

GC-ICPMS Coupled gas chromatography-inductively coupled plasma mass spectrometry

Hg Mercury
$\mathrm{Hg}^{0}$ Elemental mercury

$\mathrm{Hg}^{2+}$ Mercuric mercury

ICP-SFMS Sector field inductively coupled plasma-mass spectrometry

I-Hg Inorganic mercury

IU International unit

MeHg Methylmercury

NIST National Institute of Standards and Technology

SD Standard deviation

SRM Standard Reference Material

\section{Competing interests}

The author(s) declare that they have no competing interests.

\section{Authors' contributions}

LB conceived of the study and participated in its design and coordination, performed the statistical analysis, and drafted the manuscript. BFL participated in the study design, performed the sample collection, participated in the dental examinations and sample preparation, and contributed to the preparation of the manuscript. TL participated in the study design, performed the sample collection and dental examinations, participated in the sample preparation, and contributed particularly to the Methods section of the manuscript. BIB assisted in the study design, provided expert advice on post mortal tissue sampling and contributed to the preparation of the manuscript. IM assisted in the study design, provided expert advice on post mortal tissue sampling and aided in the preparation of the manuscript. PL assisted in the study design, provided expert advice on post mortal tissue sampling and contributed to the preparation of the manuscript. BL assisted in the study design, provided expert advice on trace element analysis and analytical quality control and contributed to the preparation of the manuscript. BP performed the trace element speciation analysis and aided in the preparation of the manuscript. MV assisted in the study design, provided expert advice and contributed to the preparation of the manuscript.

All authors read and approved the final manuscript.

\section{Acknowledgements}

Sissel Hjellestad is gratefully acknowledged for excellent technical assistance during sample collection. Andreas Myking and Anne Chr. Johannessen are acknowledged for constructive discussions. This project was supported 
by the Centre for Clinical Dental Research at the Faculty of Dentistry, University of Bergen.

\section{References}

I. Clarkson TW, Magos L, Myers G]: The toxicology of mercury current exposures and clinical manifestations. $N$ Engl J Med 2003, 349: $1731-1737$

2. Socialstyrelsen: Kvicksilver/amalgam hälsorisker (LEK-rapporten). Rapport från socialstyrelsens expertgrupp med uppgift att utreda effekter av lågdosexponering för kvicksilver Stockholm: Socialstyrelsen; 1987.

3. Socialstyrelsen: Blir man sjuk av amalgam? Rapport från Socialstyrelsens expertgrupp Stockholm: Socialstyrelsen; 1994.

4. USPHS: Dental amalgam: a scientific review and recommended public health service strategy for research, education, and regulation. US Public Health Service Committee to Coordinate Environmental Health and Related Programs Subcommittee on Risk Management 1993 [http://www.health.gov/environment/ amalgam I/ct.htm]. Washington DC: U.S. Department of Health and Human Services, Public Health Service Accessed September 27, 2007

5. Health Canada: The Safety of Dental Amalgam. Minister of Supply and Services Canada 1996 [http://www.hc-sc.gc.ca/dhp-mps/ alt formats/hpfb-dgpsa/pdf/md-im/dent amalgam e.pdf]. Accessed September 27, 2007

6. Norwegian Board of Health: The use of dental filling materials in Norway. 1999 [http://www.helsetilsynet.no/upload/Publikasjoner/ andrepublikasjoner/use dental filling materials norway ik2675.pdf]. Oslo: Norwegian Board of Health Accessed September 27, 2007

7. Gay DD, Cox RD, Reinhardt JW: Chewing releases mercury from fillings. Lancet 1979, I:985-986.

8. Björkman L, Lind B: Factors influencing mercury evaporation rate from dental amalgam fillings. Scand J Dent Res 1992, I 00:354-360.

9. Nylander M, Friberg L, Lind B: Mercury concentrations in the human brain and kidneys in relation to exposure from dental amalgam fillings. Swed Dent J 1987, I I:179- I87.

10. Sällsten G, Thoren J, Barregård L, Schutz A, Skarping G: Long-term use of nicotine chewing gum and mercury exposure from dental amalgam fillings. J Dent Res 1996, 75:594-598.

II. Kingman A, Albertini T, Brown LJ: Mercury concentrations in urine and whole blood associated with amalgam exposure in a US military population. J Dent Res 1998, 77:46|-47|

12. International Programme on Chemical Safety: Environmental health criteria I/8. Inorganic mercury Geneva: World Health Organization; 1991.

13. Vahter M, Åkesson A, Lind B, Björs U, Schutz A, Berglund M: Longitudinal study of methylmercury and inorganic mercury in blood and urine of pregnant and lactating women, as well as in umbilical cord blood. Environ Res 2000, 84: 186-194.

14. Berglund M, Lind B, Björnberg KA, Palm B, Einarsson O, Vahter M: Inter-individual variations of human mercury exposure biomarkers: a cross-sectional assessment. Environ Health 2005, 4:20.

15. Rodushkin I, Ödman F, Olofsson R, Axelsson MD: Determination of 60 elements in whole blood by sector field inductively coupled plasma mass spectrometry. Journal of Analytical Atomic Spectrometry 2000, I 5:937-944.

16. Axelsson MD, Rodushkin I: Multi-element analysis of body fluids by double-focusing ICP-MS. Transworld Res Network Recent Res Devel Pure \& Applied Chem 200I, 5:5I-66.

17. Engström E, Stenberg A, Senioukh S, Edelbro R, Baxter DC, Rodushkin I: Multi-elemental characterization of soft biological tissues by inductively coupled plasma-sector field mass spectrometry. Analytica Chimica Acta 2004, 52 I : I23- I 35.

18. Rodushkin I, Axelsson MD: Application of double focusing sector field ICP-MS for multielemental characterization of human hair and nails. Part I. Analytical methodology. Sci Total Environ 2000, 250:83-100.

19. Rodushkin I, Engström E, Stenberg A, Baxter DC: Determination of low-abundance elements at ultra-trace levels in urine and serum by inductively coupled plasma-sector field mass spectrometry. Anal Bioanal Chem 2004, 380(2):247-257.

20. Analytica [http://www.analytica.se]. Accessed September 27, 2007

21. Baxter DC, Rodushkin I, Engström E, Klockare D, Waara H: Methylmercury measurement in whole blood by isotope-dilution
GC-ICPMS with 2 sample preparation methods. Clin Chem 2007, 53:III-116.

22. NIST/SEMATECH e-Handbook of Statistical Methods [http://www.itl.nist.gov/div898/handbook/prc/section I/prc/6.htm]. Accessed September 27, 2007

23. Olstad ML, Holland RI, Wandel N, Pettersen AH: Correlation between amalgam restorations and mercury concentrations in urine. J Dent Res 1987, 66: II79-I I82.

24. Ahlqwist $M$, Bengtsson C, Furunes B, Hollender L, Lapidus L: Number of amalgam tooth fillings in relation to subjectively experienced symptoms in a study of Swedish women. Community Dent Oral Epidemiol 1988, 16:227-231.

25. Ahlqwist $M$, Bengtsson $C$, Lapidus L: Number of amalgam fillings in relation to cardiovascular disease, diabetes, cancer and early death in Swedish women. Community Dent Oral Epidemiol 1993, 2 I:40-44.

26. Björkman L, Pedersen NL, Lichtenstein P: Physical and mental health related to dental amalgam fillings in Swedish twins. Community Dent Oral Epidemiol 1996, 24:260-267.

27. Factor-Litvak P, Hasselgren G, Jacobs D, Begg M, Kline J, Geier J, Mervish N, Schoenholtz S, Graziano J: Mercury derived from dental amalgams and neuropsychologic function. Environ Health Perspect 2003, I I I:719-723.

28. Bates MN, Fawcett J, Garrett N, Cutress T, Kjellstrom T: Health effects of dental amalgam exposure: a retrospective cohort study. Int J Epidemiol 2004, 33:894-902.

29. Bellinger DC, Daniel D, Trachtenberg F, Tavares M, McKinlay S: Dental amalgam restorations and children's neuropsychological function: the New England Children's Amalgam Trial. Environ Health Perspect 2007, I I 5:440-446.

30. Kingman A, Albers JW, Arezzo JC, Garabrant DH, Michalek JE: Amalgam exposure and neurological function. Neurotoxicology 2005, 26:24I-255.

31. Buzalaf MA, Pessan JP, Alves KM: Influence of growth rate and length on fluoride detection in human nails. Caries Res 2006, 40:231-238.

32. Grandjean P, Budtz-Jorgensen E: Total imprecision of exposure biomarkers: implications for calculating exposure limits. Am I Ind Med 2007, 50:712-719.

33. Vahter ME, Mottet NK, Friberg LT, Lind SB, Charleston JS, Burbacher TM: Demethylation of methyl mercury in different brain sites of Macaca fascicularis monkeys during long-term subclinical methyl mercury exposure. Toxicol Appl Pharmacol 1995, I 34:273-284.

34. Björkman L, Mottet K, Nylander M, Vahter M, Lind B, Friberg L: Selenium concentrations in brain after exposure to methylmercury: relations between the inorganic mercury fraction and selenium. Arch Toxicol 1995, 69:228-234.

35. Weihe P, Grandjean P, Debes F, White R: Health implications for Faroe islanders of heavy metals and PCBs from pilot whales. Sci Total Environ 1996, 186:141-148.

36. Pedersen MB, Hansen JC, Mulvad G, Pedersen HS, Gregersen M, Danscher $G$ : Mercury accumulations in brains from populations exposed to high and low dietary levels of methyl mercury. Concentration, chemical form and distribution of mercury in brain samples from autopsies. Int J Circumpolar Health 1999 , 58:96-107.

37. Passos CJ, Mergler D, Lemire M, Fillion M, Guimaraes JR: Fish consumption and bioindicators of inorganic mercury exposure. Sci Total Environ 2007, 373:68-76.

38. Yarema MC, Becker CE: Key concepts in postmortem drug redistribution. Clin Toxicol (Phila) 2005, 43:235-24I.

39. Jokstad A, Thomassen Y, Bye E, Clench-Aas J, Aaseth J: Dental amalgam and mercury. Pharmacol Toxicol 1992, 70:308-313.

40. Vamnes JS, Eide R, Isrenn R, Høl PJ, Gjerdet NR: Blood mercury following DMPS administration to subjects with and without dental amalgam. Sci Total Environ 2003, 308:63-7I.

4I. Lygre GB, Høl PJ, Eide R, Isrenn R, Gjerdet NR: Mercury and silver in saliva from subjects with symptoms self-related to amalgam fillings. Clin Oral Investig 1999, 3:216-218.

42. af Geijersstam E, Sandborgh-Englund G, Jonsson F, Ekstrand J: Mercury uptake and kinetics after ingestion of dental amalgam. J Dent Res 2001, 80:1793-1796.

43. Barregård L, Sällsten G, Järvholm B: People with high mercury uptake from their own dental amalgam fillings. Occup Environ Med 1995, 52:124-128. 
44. Jonsson F, Sandborgh-Englund G, Johanson G: A compartmental model for the kinetics of mercury vapor in humans. Toxicol Appl Pharmacol 1999, 155:161-168.

45. Custodio HM, Harari R, Gerhardsson L, Skerfving S, Broberg K: Genetic influences on the retention of inorganic mercury. Arch Environ Occup Health 2005, 60: 17-23.

46. Gundersen N, Lie A: Kvikksølveksponering på tannlegekontorer. Nor Tannlegefor Tid 198I, 91:219-226.

47. Lenvik K, Woldbæk T, Halgard K: Kvikksølveksponering blant tannhelsepersonell. Nor Tannlegeforen Tid 2006, I I 6:350-356.

48. Kosta L, Byrne AR, Zelenko V: Correlation between selenium and mercury in man following exposure to inorganic mercury. Nature 1975, 254:238-239.

49. Nylander M, Friberg L, Eggleston D, Björkman L: Mercury accumulation in tissues from dental staff and controls in relation to exposure. Swed Dent J 1989, 13:235-243.

50. Falnoga I, Tusek-Znidaric M, Horvat M, Stegnar P: Mercury, selenium, and cadmium in human autopsy samples from Idrija residents and mercury mine workers. Environ Res 2000, 84:2II-2I 8 .

5I. Weiner JA, Nylander M: The relationship between mercury concentration in human organs and different predictor variables. Sci Total Environ 1993, I38: I0I-II5.

52. Khayat Al: Disposition of metallic mercury vapor and mercuric chloride in adult and fetal tissues: influence of pretreatment with ethyl alcohol, aminotriazole, selenium, and tellurium. PhD-thesis. Uppsala University, Abstracts of Uppsala dissertations from the Faculty of Pharmacy 1985.

53. Saxe SR, Wekstein MW, Kryscio RJ, Henry RG, Cornett CR, Snowdon DA, Grant FT, Schmitt FA, Donegan SJ, Wekstein DR, Ehmann WD, Markesbery WR: Alzheimer's disease, dental amalgam and mercury. I Am Dent Assoc 1999, 130:191-199.

54. Nylander $M$, Weiner J: Relation between mercury and selenium in pituitary glands of dental staff. $\mathrm{Br}$ J Ind Med 1989, 46:75।-752.

55. Björkman L: Studies on dental amalgam and mercury exposure, accumulation and effects. PhD-thesis. Institute of Environmental Medicine, Karolinska institutet 1995.

56. Nylander M, Friberg L, Weiner J: Muscle biopsy as an indicator for predicting mercury concentrations in the brain. $\mathrm{Br} J$ Ind Med 1990, 47:575-576.

57. Horvat M: Current status and future needs for biological and environmental reference materials certified for methylmercury compounds. Chemosphere 1999, 39:1167-1179.

58. NRCC, Institute for National Measurement Standards: LUTS-I. Non Defatted Lobster Hepatopancreas. Reference Materia for Trace Metals. Ottawa: National Research Council of Canada. Institute for National Measurement Standards 2005 [http://inms-ienm.nrccnrc.gc.ca/calserv/crm files e/LUTSI certificate.pdf]. Accessed September 27,2007

\section{Publish with Bio Med Central and every scientist can read your work free of charge}

"BioMed Central will be the most significant development for disseminating the results of biomedical research in our lifetime. "

Sir Paul Nurse, Cancer Research UK

Your research papers will be:

- available free of charge to the entire biomedical community

- peer reviewed and published immediately upon acceptance

- cited in PubMed and archived on PubMed Central

- yours - you keep the copyright

Submit your manuscript here:

http://www.biomedcentral.com/info/publishing_adv.asp
BioMedcentral 